determination of sward composition. Rather surprisingly, no mention is made of the importance of chemical interactions. This is an area of basic ecological research which may eventually explain many species interrelationships in grassland and which could be profoundly important in grassland management.

Are legumes in turf more effective in maintaining a nitrate supply in the soil than the application of nitrogenous fertilisers? What are the long term effects of various mowing and fertiliser regimes? Such a question could be answered by detailed studies of swards with recorded management details. The development of new cultivars continues as a result of the work of such institutions as the Welsh Plant Breeding Station at Aberystwyth, but there is a need for better evaluation of cultivars under different soil, climatic and management regimes. The expense of mowing could be alleviated by the development of slow-growing cultivars (a line of research currently being pursued at Sheffield University). If mowing techniques could be made just $5 \%$ more efficient, the resultant saving would amount to about $£ 4$ million a year.

These and many other possible research developments are proposed in the NERC review. In view of the low current investment in such research, only $0.1 \%$ of the annual maintenance costs of amenity grassland, there does seem to be a sound economic argument for the expansion of ecological research in this area.

\section{Plate tectonics in the Arabian Pan-African?}

\section{from G. C. Brown and J. V. Hepworth}

DURING the past 15-20 years, students of African geology have recognised three important ancient cratonic shield areas in West and South Africa, containing Archaean and early Proterozoic rocks, separated by younger, later Proterozoic 'mobile belts'. Pan-African ages (500-650 Ma), extended back to 1,100 Ma, characterise younger rocks of the latter group and such ages are recorded extensively in Arabia. Indeed, the so-called Arabian-Nubian shield is made of calc-alkaline igneous and thick clastic sedimentary sequences which have suffered greenschist metamorphism and may be an extension of the $\mathrm{N}-\mathrm{S}$ trending Mozambique belt of East Africa. Some linear belts of ultramafic, possibly ophiolitic rocks, trending NE$\mathrm{SW}$, also traverse the area. No rocks older than $1,100 \mathrm{Ma}$ have been identi- fied in this shield segment which, at outcrop, is detached from the remainder of the African Precambrian by Phanerozoic cover rocks.

Two possible interpretations of shield development arose during a recent conference at the Institute of Applied Geology at Jeddah* and stimulated considerable debate. The first requires a foundation of older crust, greatly tectonised and thermally overprinted, upon which volcanoclastic sequences were stabilised and through which granites were intruded.

This is the ensialic evolutionary model which has been applied traditionally to mobile belt development elsewhere in Africa. The alternative, ensimatic model, first proposed by Greenwood and others at a Royal Society discussion meeting in 1976. requires the operation of plate tectonic processes with ocean openings and closings at sutures. Protagonists of this model see each suture as the site of a former subduction zone, each tagged with ophiolite and calc-alkaline magma occurrences.

In developing the latter, ensimatic model, correlations in time and space with modern subduction zones led to models being proposed based on South West Pacific back-arc marginal basins and island arcs which would have been marginal to the North East African foreland. Support came particularly from the interpretation of strontium isotopes for granites and associated volcanics (R. J. Fleck, US Geological Survey) which are of mantle-derivation and rather similar to those associated with modern destructive margins. Trends followed by calc-alkaline magmas and their probable subductionrelated genesis (W. S. Fyfe, Western Ontario), the interpretation of basicultrabasic masses as ophiolitic sutures (A. Al-Shanti, Institute of Geology, Jeddah; 1. G. Gass, Open University; R. M. Shackleton, University of Leeds) and the evolution of sediments from deep water marine to shallow marine and continental varieties over $500 \mathrm{Ma}$ D. G. Hadley, US Gcological Survey) were taken to favour ensimatic "cratonisation' of the Arabian-Nubian shield.

The contrary view, in the broader context of contemporaneous 'PanAfrican' evolution elsewhere (A. Kröner, Mainz) was supported by the notion of a geosynclinal cycle, based upon thinned, older continental material under tension. Implicit in this argument is the existence of as yet unrecognised pre-1,100 Ma crust in the Arabian shield, although J. V. Hepworth (Institute of Geological Sciences), S. M. El-Rabaa (University of Khartoum) and J. Vail (Portsmouth Polytechnic) correlated northwards into

*February 5-16.
Arabia, Mozambiquian structures of the Ugandan and Sudanese areas.

If such ancient cratonic material, thermally and tectonically overprinted with Mozambiquian structures is recognised ultimately, then calc-alkaline magma generation by subcrustal convection with tensional thinning or rifting (as often applied to Archaean crustal features) would be possible. But the existence of older craton does not rule out compressional ensialic plate margin development of Andean type: ensialic development might still be consistent with plate models.

Although considerable data from the Arabian Shield were claimed to support the ensimatic model, an overriding need was recognised for more detailed spatial, geochemical and isotopic studies of all rock types and, particularly, the ostensible ophiolite occurrences. However, the successful application of either island arc or Andean plate marginal models to the late Proterozoic should not surprise us, especially if crustal development is a function of the Earth's exponentially decaying heat productivity: after a week in Jeddah. it seems that Pan-African tectonic styles may well prove to be more closely related to the present day than those of the Archaean.

G. C. Brown is a lecturer in the Department of Earth Sciences at the Open University and J.V. Hepworth is at the Institute of Geological Sciences.

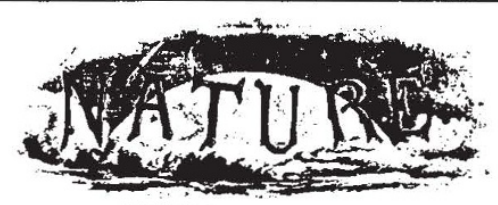

\section{A hundred years ago}

With reference to a note in Nature (vol. xvii. p. 38) respecting the uninflammability of eucalyptus, $\mathrm{Mr}$. A. Nicols writes that this must be a mistake, as in Australia the wood is extensively used as fuel. Acclimatisation of these really valuable trees, Mr. Nicols thinks, should be strongly supported. They yicld timber of immense size and strength, durable alike in dry or wet situations, and more proof against the attacks of termites than many other woods, and some work up into beautiful furniture. They would probably thrive wherever the mean annual temperature is not below $60^{\circ}$, or, roughly speaking, over an area of about one-half of the habitable region of the earth.

From Nature 17, 14 March, 391, 392; 1878.

\section{Erratum}

The reference to Readhead et al. in the article 'Nuclear jet in a radio galaxy' in last week's News and Views was inadvertently omitted. It was to the article on page 131 in the same issue $(272,131 ; 1978)$. 